\title{
Effect of different sources and doses of sulphur on yield, nutrient content and uptake by spring wheat
}

\author{
Evelin Kármen Juhász ${ }^{1,2}$ - Andrea Balláné Kovács² \\ ${ }^{1}$ University of Debrecen, Kálmán Kerpely Doctoral School, Debrecen \\ ${ }^{2}$ University of Debrecen, Faculty of Agricultural and Food Sciences and Environmental Management, Institute of Agricultural Chemistry and \\ Soil Science, Debrecen \\ evelinjuhasz570@gmail.com
}

\begin{abstract}
SUMMARY
The objective of this study was to investigate the effect of two sulphur forms (sulphate and tiosulphate) in combination with three different N:S ratios on the yield of spring wheat and total $N$ - and S-content and uptake by the aboveground biomass on chernozem and sandy soil. In the greenhouse experiment, the effects of two sulphur forms were compared: sulphate $\left(\mathrm{SO}_{4}^{2-}\right)$ and thiosulphate $\left(\mathrm{S}_{2} \mathrm{O}_{3}{ }^{2-}\right)$. The sulphate was applied as potassium-sulphate $\left(\mathrm{K}_{2} \mathrm{SO}_{4}\right)$ and thiosulphate as ammonium-thiosulphate $\left(\left(\mathrm{NH}_{4}\right)_{2} \mathrm{~S}_{2} \mathrm{O}_{3}\right)$. Increasing doses of both sulphur forms (24, 60, 120

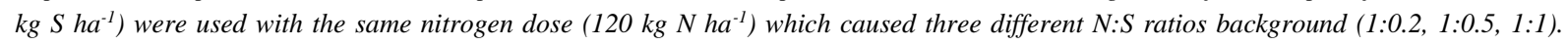
Nitrogen was supplied in the form of monoammonium-phosphate (MAP), ammonium-nitrate and ammonium-thiosulphate. Plant samples were taken in three different development stages of spring wheat based on the BBCH scale: at the stage of BBCH 30-32 (stem elongation), BBCH 65-69 (flowering) and BBCH 89 (ripening). The total nitrogen and total sulphur content of plant at different development stages and also wheat grain were measured by Elementar Vario EL type CNS analyser. The nutrient uptake by plant and grain was calculated from the yield of spring wheat and the $N$ and $S$ content of plant. The grain yield on chernozem soil ranged between 6.31 and $12.13 \mathrm{~g} /$ pot. All fertilised treatments significantly increased the grain yield compared to the control. The highest yield was obtained in the case of the application of 120 $\mathrm{kg} \mathrm{N} \mathrm{ha}^{-1}$ and $60 \mathrm{~kg} \mathrm{~S} \mathrm{ha-1}$ in sulphate form. The grain yield on sandy soil varied from 2.53 to $6.62 \mathrm{~g} /$ pot. The fertilised treatments significantly enhanced the yield compared to the control. The highest yield was observed in the case of the application of $120 \mathrm{~kg} \mathrm{~N} \mathrm{ha}^{-1}$ and $60 \mathrm{~kg} S \mathrm{ha}$ in thiosulphate form. On chernozem soil the increasing doses of sulphur (24, 60, $120 \mathrm{~kg} \mathrm{~S} \mathrm{ha-1)} \mathrm{with} \mathrm{the} \mathrm{same} \mathrm{N} \mathrm{dose} \mathrm{(120} \mathrm{kg} N$ ha-1) increased the $N$-content of spring wheat at all development stages and in the grain. The treatments with different sulphur sources did not cause further changes in the N-content. On sandy soil in the most cases the N-content did not change significantly as a result of increasing sulphur doses. The treatments with sulphate form basically resulted higher nitrogen-content than treatments with thiosulphate form. The treatments with increasing sulphur doses resulted higher S-content on both of chernozem and sandy soil in the case of all development stage. Comparing the effect of the applied sulphur sources on the S-content it can be stated that at the stage of BBCH 30-31 and 65-69 the treatments with sulphate form resulted higher sulphur-content. At the stage of BBCH 89 there was no significant differences in $S$-content of grain as a result of different sulphur-sources.
\end{abstract}

Keywords: sulphate; thiosulphate; spring wheat; yield; $N$-, S-content

\section{INTRODUCTION}

Sulphur is an essential nutrient for plants. Proper sulphur supply has a positive effect on the vegetative growth of plants, increases green weight, modifies protein content, and influences the amount and proportion of protein-forming amino acids (Aula et al., 2019). Nitrogen plays a central role in plant productivity as well because it is a major component of amino acids, proteins, nucleic acids, and chlorophyll. Nitrogen promotes rapid growth, increases leaf size and quality, hastens crop maturity, and promotes seed development (Parsons and Tinsley, 1975). Nitrogen and sulphur are equally important protein components and the correct N:S ratio significantly contributes to grain quality as well as to optimal yield of crop plants (Klikocka et al., 2018).

More and more researchers indicate a positive effect of sulphur fertilisation on cereal crop production (Blake-Kalff et al., 2000; Zhao et al., 2006; Järvan et al., 2008). The positive response of cereal crops to sulphur fertilisation was caused by the fact that the initial levels of sulphur available for plants in soil were low (Olfs et al., 2012). Many European countries are facing a problem of low plant-available sulphur levels in soil due to the decreasing use of superphosphate and sulphate-containing fertilisers and the massive decrease in the inputs of $\mathrm{S}$ from atmospheric deposition (Schnug and Haneklaus, 1998; Messick et al., 2005). Insufficient levels of plant available sulphur in soil block the positive effect of nitrogen fertilisation - yield is not increasing, and the excessive amount of nitrogen which was not consumed by plants becomes an environmental pollutant (Jamal et al., 2010).

The S-containing fertilisers are available mostly in three chemical forms: sulphate $\left(\mathrm{SO}_{4}{ }^{2-}\right)$, elemental $\mathrm{S}\left(\mathrm{S}^{0}\right)$ and thiosulphate $\left(\mathrm{S}_{2} \mathrm{O}_{3}{ }^{2-}\right)$ (Germida and Janzen, 1993; McGrath et al., 1996). Of these, the sulphate and elemental sulphur forms have received much more attention in terms of their chemical reactions in soils and availability of $\mathrm{S}$ to crops. Thiosulphate, especially ammonium thiosulphate can be used as sulphur fertiliser materials. Ammonium thiosulphate has the benefit of supplying both sulphur $(26 \%)$ and nitrogen (12\%) (Dick, 2008). However, thiosulphate reactions in soil have been slightly researched. A pot experiment by Janzen and Bettany (1986) presented that oxidation of $\mathrm{S}_{2} \mathrm{O}_{3}{ }^{2-}$ fertiliser was almost complete in 25 day, but because of the involvement of microorganisms in the process, some of the oxidised S was immobilised, 
making it less available than the same amount of $\mathrm{SO}_{4}{ }^{2-}$ in the short term. Most of the studies concerning $\mathrm{S}_{2} \mathrm{O}_{3}{ }^{2-}$ focus on its inhibitory effects on nitrification, urea hydrolysis and potential improvement of $\mathrm{N}$ efficiency (Janzen and Bettany, 1986; Sullivan and Havlin, 1992; Saad et al., 1996).

The objective of this study was to investigate the effect of two sulphur forms (sulphate and tiosulphate) in combination with three different $\mathrm{N}: \mathrm{S}$ ratio $(1: 0.2$, $1: 0.5,1: 1)$ on the yield of spring wheat and total $\mathrm{N}$ - and $\mathrm{S}$-content and uptake by the aboveground biomass on chernozem and sandy soil.

\section{MATERIALS AND METHODS}

The greenhouse pot experiment was conducted on two different soils: calcareous chernozem soil of Debrecen-Látókép and sandy soil with humus content of Pallag. The main parameters of experimental soils are shown in the Table 1.

Table 1. The main parameters of experimental soils

\begin{tabular}{lcc}
\hline & $\begin{array}{c}\text { Chernozem soil } \\
\text { (Debrecen-Látókép) }\end{array}$ & $\begin{array}{c}\text { Sandy soil } \\
\text { (Pallag) }\end{array}$ \\
\hline $\mathrm{pH}(\mathrm{KCl})$ & 5.68 & 5.38 \\
$\mathrm{Hu} \%$ & 3.11 & 1.00 \\
$\mathrm{~K}_{\mathrm{A}}$ & 39 & 30 \\
$\mathrm{AL}-\mathrm{P}_{2} \mathrm{O}_{5}\left(\mathrm{mg} \mathrm{kg}^{-1}\right)$ & 263.6 & 248.2 \\
$\mathrm{AL}-\mathrm{K}_{2} \mathrm{O}\left(\mathrm{mg} \mathrm{kg}^{-1}\right)$ & 180.0 & 278.0 \\
$\mathrm{KCl}-\mathrm{SO}_{4}{ }^{2-}\left(\mathrm{mg} \mathrm{kg}^{-1}\right)$ & 4.98 & 6.43 \\
\hline
\end{tabular}

The chernozem soil was well supplied with N, very well with $\mathrm{P}$ and poorly with $\mathrm{K}$. The sandy soil was moderately supplied with $\mathrm{N}$, adequate with $\mathrm{P}$ and very well with K. According to Brook (1979); Tiwari et al. (1985); Balanagaudar and Satyanlyana (1990) $10 \mathrm{mg} \mathrm{kg}^{-1}$ in $\mathrm{KCl}$ extract is widely reported as critical limit for plant available sulphur in the soil. Based on these studies the sulphur content of our experimental soils is not sufficient for the plant development.

To establish the experiment, $10 \mathrm{~kg}$ of air dry soil was measured into the experimental pots. The indicator plant was the Stanga variety of spring wheat. The moisture content of soils was set up to $60 \%$ of the water holding capacity of the field. Pots were weighed daily and the missing water was supplemented with ion exchange water.

In the experiment, the effects of two sulphur forms were compared: the sulphate $\left(\mathrm{SO}_{4}{ }^{2-}\right)$ and the thiosulphate $\left(\mathrm{S}_{2} \mathrm{O}_{3}{ }^{2-}\right)$. The sulphate was applied as potassium-sulphate $\left(\mathrm{K}_{2} \mathrm{SO}_{4}\right)$ and thiosulphate as ammonium-thiosulphate $\left(\left(\mathrm{NH}_{4}\right)_{2} \mathrm{~S}_{2} \mathrm{O}_{3}\right)$. Increasing doses of both sulphur forms $\left(24,60,120 \mathrm{~kg} \mathrm{~S} \mathrm{ha}^{-1}\right)$ were used with the same nitrogen dose $\left(120 \mathrm{~kg} \mathrm{~N} \mathrm{ha}^{-1}\right)$ which caused three different $\mathrm{N}: \mathrm{S}$ ratios background (1:0.2, $1: 0.5,1: 1)$. Nitrogen was supplied in the form of monoammonium-phosphate (MAP), ammoniumnitrate and ammonium-thiosulphate. The phosphorus and potassium needs of wheat were added MAP, $\mathrm{KCl}$ and $\mathrm{K}_{2} \mathrm{SO}_{4}$. The solid phase fertilisers were applied at the same time with sowing. There were 7 treatments with three replications and the treatment plan of the experiment is shown in the Table 2.

Table 2. Rates of fertilisers applied in the pot experiment

\begin{tabular}{|c|c|c|c|c|}
\hline $\begin{array}{c}\text { Number of } \\
\text { treatment }\end{array}$ & $\mathrm{N}: S$ ratio & Sulphur forms & $\begin{array}{c}\text { Nitrogen doses } \\
(\mathrm{g} / 10 \mathrm{~kg})\end{array}$ & $\begin{array}{c}\text { Sulphur doses } \\
(\mathrm{g} / \mathbf{1 0 k g})\end{array}$ \\
\hline 1. & control & - & - & - \\
\hline 2. & 1:0.2 & $\mathrm{SO}_{4}{ }^{2-}$ & 0.4 & 0.08 \\
\hline 3. & $1: 0.5$ & $\mathrm{SO}_{4}^{2-}$ & 0.4 & 0.2 \\
\hline 4. & $1: 1$ & $\mathrm{SO}_{4}{ }^{2-}$ & 0.4 & 0.4 \\
\hline 5. & $1: 0.2$ & $\mathrm{~S}_{2} \mathrm{O}_{3}{ }^{2-}$ & 0.4 & 0.08 \\
\hline 6. & $1: 0.5$ & $\mathrm{~S}_{2} \mathrm{O}_{3}{ }^{2-}$ & 0.4 & 0.2 \\
\hline 7. & $1: 1$ & $\mathrm{~S}_{2} \mathrm{O}_{3}{ }^{2-}$ & 0.4 & 0.4 \\
\hline
\end{tabular}

Plant samples were taken in three different development stages of spring wheat based on the $\mathrm{BBCH}$ scale: at the stage of $\mathrm{BBCH} 30-32$ (stem elongation), $\mathrm{BBCH}$ 65-69 (flowering) and $\mathrm{BBCH} 89$ (ripening).

Harvested plants were dried and dry biomass weights of wheat were determined. Dry samples were milled for the analysis. The total nitrogen and total sulphur content of plant at different development stages and also wheat grain were measured by Elementar Vario EL type CNS analyser. The nutrient uptake by plant and grain was calculated from the yield of spring wheat and the $\mathrm{N}$ and $\mathrm{S}$ content of plant.
For statistical analysis of experimental results IBM SPSS Statistics 22 and Microsoft Excel 2016 programs were used. The mean values of each treatment group were subjected to comparisons analysis using the OneWay ANOVA (significance level of $\mathrm{p}<0.05$ ) with post hoc comparisons using Tukey test.

\section{RESULTS AND DISCUSSION}

\section{The dry biomass of spring wheat at different development stages}

On chernozem there were no significant effects on dry biomass of different sulphur forms and different $\mathrm{N}: \mathrm{S}$ ratios (Table 3) at the stage of $\mathrm{BBCH} 30-32$. 
On sandy soil, greater biomass growth was observed compared to the biomass value of chernozem soil. On sandy soil, significantly higher biomass production was detected due to the treatments $2(24 \mathrm{~kg}$ $\left.\mathrm{S} \mathrm{ha}{ }^{-1}\right)$ and $3\left(60 \mathrm{~kg} \mathrm{~S} \mathrm{ha}^{-1}\right)$ compared to the control treatment. Analysing the effect of different sulphur forms on biomass, the treatments with sulphate form tended to increase the dry biomass compared to the tiosulphate treatments. There were no significant variances between the different $\mathrm{N}: \mathrm{S}$ ratio treatments, but there were visible some tendencies to the yield decrease with increasing $S$ rate.

Table 3. The changes of dry biomass at different development stages of spring wheat

\begin{tabular}{|c|c|c|c|c|c|}
\hline $\begin{array}{c}\text { Treatment } \\
\text { number }\end{array}$ & Sulphur forms & $\mathrm{N}: S$ ratio & $\begin{array}{c}\text { BBCH 30-32 } \\
\text { g/2 plants } \\
\end{array}$ & $\begin{array}{c}\text { BBCH } 65-69 \\
\text { g/2 plants } \\
\end{array}$ & $\begin{array}{c}\text { BВCH } 89 \\
\text { grain (g/pot) }\end{array}$ \\
\hline \multicolumn{6}{|c|}{ Chernozem soil } \\
\hline 1. & - & control & $0.24 \mathrm{a}$ & $0.61 \mathrm{a}$ & $6.31 \mathrm{a}$ \\
\hline 2. & $\mathrm{SO}_{4}{ }^{2-}$ & $1: 0.2$ & $0.30 \mathrm{a}$ & $0.80 \mathrm{a}$ & $12.04 \mathrm{~b}$ \\
\hline 3. & $\mathrm{SO}_{4}^{2-}$ & $1: 0.5$ & $0.25 \mathrm{a}$ & $0.83 \mathrm{a}$ & $12.13 b$ \\
\hline 4. & $\mathrm{SO}_{4}^{2-}$ & $1: 1$ & $0.26 \mathrm{a}$ & $0.72 \mathrm{a}$ & $10.53 b$ \\
\hline 5. & $\mathrm{~S}_{2} \mathrm{O}_{3}^{2-}$ & $1: 0.2$ & $0.34 \mathrm{a}$ & $0.71 \mathrm{a}$ & $10.03 \mathrm{~b}$ \\
\hline 6. & $\mathrm{~S}_{2} \mathrm{O}_{3}{ }^{2-}$ & $1: 0.5$ & $0.29 \mathrm{a}$ & $0.93 \mathrm{a}$ & $10.53 b$ \\
\hline 7. & $\mathrm{~S}_{2} \mathrm{O}_{3}{ }^{2-}$ & $1: 1$ & $0.28 \mathrm{a}$ & $0.69 \mathrm{a}$ & $10.01 \mathrm{~b}$ \\
\hline \multicolumn{6}{|c|}{ Sandy soil } \\
\hline 1. & - & control & $0.17 \mathrm{a}$ & $0.27 \mathrm{a}$ & $2.53 \mathrm{a}$ \\
\hline 2. & $\mathrm{SO}_{4}^{2-}$ & $1: 0.2$ & $0.54 \mathrm{c}$ & $0.64 \mathrm{ab}$ & $6.10 \mathrm{~b}$ \\
\hline 3. & $\mathrm{SO}_{4}{ }^{2-}$ & $1: 0.5$ & $0.51 b c$ & $0.60 \mathrm{ab}$ & $6.24 b$ \\
\hline 4. & $\mathrm{SO}_{4}{ }^{2-}$ & $1: 1$ & $0.40 \mathrm{abc}$ & $0.63 \mathrm{ab}$ & $5.37 \mathrm{ab}$ \\
\hline 5. & $\mathrm{~S}_{2} \mathrm{O}_{3}{ }^{2-}$ & $1: 0.2$ & $0.35 \mathrm{abc}$ & $0.80 \mathrm{~b}$ & $6.45 b$ \\
\hline 6. & $\mathrm{~S}_{2} \mathrm{O}_{3}{ }^{2-}$ & $1: 0.5$ & $0.28 \mathrm{ab}$ & $0.72 \mathrm{ab}$ & $6.62 b$ \\
\hline 7. & $\mathrm{~S}_{2} \mathrm{O}_{3}{ }^{2-}$ & $1: 1$ & $0.22 \mathrm{a}$ & $0.62 \mathrm{ab}$ & $6.31 \mathrm{~b}$ \\
\hline
\end{tabular}

Note: Data marked with the same letter is not significantly different at the significant level of $\mathrm{p}<0.05$

At the stage of $\mathrm{BBCH} 65-69$, the treatments with different $\mathrm{N}: \mathrm{S}$ ratio and the applied sulphur sources did not cause any significant differences in the dry biomass on chernozem soil.

On sandy soil, the fertilised treatments tended to increase the dry biomass production, but only at treatment 5 was achieved statistically higher value compared to the control treatment. In addition, there was no significant effect in the case of application of the sulphur forms or the different $\mathrm{N}: \mathrm{S}$ ratio treatments.

Analysis of the results of Table 3 showed a significant beneficial effect of $\mathrm{N}$ and $\mathrm{S}$ fertilisation on the grain yield of spring wheat on both of chernozem and sandy soil.

The grain yield on chernozem soil ranged between 6.31 and $12.13 \mathrm{~g} /$ pot. All fertilised treatments significantly increased the grain yield compared to the control. The highest yield was obtained in the treatment 3 , in the case of the application of $120 \mathrm{~kg} \mathrm{~N} \mathrm{ha}^{-1}$ and 60 $\mathrm{kg} \mathrm{S} \mathrm{ha-1}$. In a study by Podleśna (2013), $\mathrm{S}$ fertilisation of winter wheat at a rate of $60 \mathrm{~kg} \mathrm{~S} \mathrm{ha}^{-1}$ led to a significant increase as well in grain yield. A study led by Fotyma (1990) on fertilisation of spring wheat with $\mathrm{S}$ showed too that the application of $60 \mathrm{~kg} \mathrm{~S} \mathrm{ha}^{-1}$ increased grain yield. He claims that $\mathrm{S}$ indirectly increases crop yield by influencing $\mathrm{N}$ transformation in the plant. Comparing the effect of sulphur forms on grain yield, a little bit higher yield was observed in the case of application of sulphate. Sangwan et al. (2018) came to the similar conclusion, in their study the yield- enhancing effect of $\mathrm{K}_{2} \mathrm{SO}_{4}$ was observed. The different $\mathrm{N}: \mathrm{S}$ ratio treatments did not cause significant effect on grain yield.

The grain yield on sandy soil varied from 2.53 to $6.62 \mathrm{~g} /$ pot. The fertilised treatments significantly enhanced the yield compared to the control. The highest yield was observed in the case of the application of 120 $\mathrm{kg} \mathrm{N} \mathrm{ha}{ }^{-1}$ and $60 \mathrm{~kg} \mathrm{~S} \mathrm{ha}{ }^{-1}$ in thiosulphate form. However, there were no significant differences between the treatments with different sulphur forms, but a slight increment was observed due to the treatment with tiosulphate form. Furthermore, the applied N:S ratios did not cause any significant differences in the grain yield.

On both the chernozem and sandy soil, a grain yield-reducing effect was observed in the case of application of the highest sulphur doses (120 kg S ha-1).

\section{The changes of total $N$ and total $S$ content of spring wheat at different development stages}

Based on the result of Table 4, the total N-content of spring wheat at the stage of $\mathrm{BBCH} 30-31$ on chernozem soil varied from $3.607 \%$ to $4.404 \%$. Very similar values were determined in spring red wheat by Reussi et al. (2008), in their experiment the N-content of plant at the stage of $\mathrm{BBCH} 30-31$ ranged from $3.72 \%$ to $4.61 \%$. Analysing the effect of the two sulphur forms, the sulphate form slightly increased the $\mathrm{N} \%$ compared to treatments with the tiosulphate. 
Statistically proved differences between the applied $\mathrm{N}: \mathrm{S}$ ratios were not found, however the increasing sulphur doses tended to increase the $\mathrm{N} \%$.

The total S-content of spring wheat ranged between $0.358 \%$ and $0.543 \%$. The maximum $\mathrm{S}$-value was observed in control treatment. In this development stage the fertilised treatment decreased the $\mathrm{S} \%$, which can be explained by the phenomenon as the effect of dilution. Considering the different sulphur forms, significantly higher S-concentration was determined in the case of treatment with sulphate form application. There were no significant differences between the studied N:S ratio treatments, but a slight increment was observed as a result of the increasing sulphur doses.

Table 4. Total $\mathbf{N}$ and total $\mathbf{S}$ content of spring wheat at different development stages

\begin{tabular}{|c|c|c|c|c|c|c|c|c|}
\hline \multirow{2}{*}{$\begin{array}{l}\text { Treatment } \\
\text { number }\end{array}$} & \multirow{2}{*}{$\begin{array}{l}\text { Sulphur } \\
\text { forms }\end{array}$} & \multirow[t]{2}{*}{$\mathrm{N}: \mathrm{S}$ ratio } & \multicolumn{2}{|c|}{$\begin{array}{c}\text { BBCH 30-31 } \\
\text { whole plant }\end{array}$} & \multicolumn{2}{|c|}{$\begin{array}{c}\text { BBCH 65-69 } \\
\text { leaves }\end{array}$} & \multicolumn{2}{|c|}{$\begin{array}{c}\text { BBCH } 89 \\
\text { grain }\end{array}$} \\
\hline & & & $\mathrm{N} \%$ & $\mathbf{S \%}$ & N\% & $\mathrm{S} \%$ & N\% & $\mathbf{S \%}$ \\
\hline \multicolumn{9}{|c|}{ Chernozem soil } \\
\hline 1. & - & control & $4.211 \mathrm{~b}$ & $0.543 \mathrm{~d}$ & $1.701 \mathrm{a}$ & $0.369 \mathrm{~cd}$ & $1.824 \mathrm{ab}$ & $0.153 \mathrm{a}$ \\
\hline 2. & $\mathrm{SO}_{4}^{2-}$ & $1: 0.2$ & $4.050 \mathrm{ab}$ & $0.446 b c$ & $2.165 b$ & $0.296 b c$ & $1.732 \mathrm{a}$ & $0.159 \mathrm{a}$ \\
\hline 3. & $\mathrm{SO}_{4}^{2-}$ & $1: 0.5$ & $4.332 \mathrm{~b}$ & $0.490 \mathrm{~cd}$ & $2.260 \mathrm{~b}$ & $0.437 \mathrm{de}$ & $1.885 b$ & $0.164 \mathrm{a}$ \\
\hline 4. & $\mathrm{SO}_{4}{ }^{2-}$ & $1: 1$ & $4.404 b$ & $0.494 \mathrm{~cd}$ & $2.219 b$ & $0.456 \mathrm{e}$ & $2.020 \mathrm{c}$ & $0.172 \mathrm{a}$ \\
\hline 5. & $\mathrm{~S}_{2} \mathrm{O}_{3}{ }^{2-}$ & $1: 0.2$ & $3.607 \mathrm{a}$ & $0.358 \mathrm{a}$ & $2.300 \mathrm{~b}$ & $0.198 \mathrm{a}$ & $1.915 b c$ & $0.169 \mathrm{a}$ \\
\hline 6. & $\mathrm{~S}_{2} \mathrm{O}_{3}{ }^{2-}$ & $1: 0.5$ & $3.952 \mathrm{ab}$ & $0.376 \mathrm{ab}$ & $2.368 b$ & $0.219 \mathrm{ab}$ & $1.920 \mathrm{bc}$ & $0.176 \mathrm{a}$ \\
\hline 7. & $\mathrm{~S}_{2} \mathrm{O}_{3}{ }^{2-}$ & $1: 1$ & $4.013 \mathrm{ab}$ & $0.392 \mathrm{ab}$ & $2.399 b$ & $0.297 b c$ & $1.941 b c$ & $0.180 \mathrm{a}$ \\
\hline \multicolumn{9}{|c|}{ Sandy soil } \\
\hline 1. & - & control & $2.139 \mathrm{a}$ & $0.475 d$ & $1.209 \mathrm{a}$ & $0.214 \mathrm{ab}$ & $2.232 \mathrm{a}$ & $0.204 \mathrm{ab}$ \\
\hline 2. & $\mathrm{SO}_{4}{ }^{2-}$ & $1: 0.2$ & $3.433 b$ & $0.358 \mathrm{a}$ & $1.888 \mathrm{c}$ & $0.246 b$ & $2.275 \mathrm{ab}$ & $0.220 \mathrm{abcc}$ \\
\hline 3. & $\mathrm{SO}_{4}^{2-}$ & $1: 0.5$ & $4.079 \mathrm{~d}$ & $0.439 \mathrm{c}$ & $1.682 b c$ & $0.355 c$ & $2.711 \mathrm{c}$ & $0.244 d$ \\
\hline 4. & $\mathrm{SO}_{4}{ }^{2-}$ & $1: 1$ & $4.218 \mathrm{e}$ & $0.452 \mathrm{~cd}$ & $1.636 \mathrm{bc}$ & $0.403 \mathrm{c}$ & $2.648 b c$ & $0.229 \mathrm{bcd}$ \\
\hline 5. & $\mathrm{~S}_{2} \mathrm{O}_{3}{ }^{2-}$ & $1: 0.2$ & $4.017 \mathrm{~cd}$ & $0.344 \mathrm{a}$ & $1.567 \mathrm{~b}$ & $0.180 \mathrm{a}$ & $2.127 \mathrm{a}$ & $0.198 \mathrm{a}$ \\
\hline 6. & $\mathrm{~S}_{2} \mathrm{O}_{3}{ }^{2-}$ & $1: 0.5$ & $3.990 \mathrm{c}$ & $0.367 \mathrm{a}$ & $1.614 b c$ & $0.189 a$ & $2.212 \mathrm{a}$ & $0.214 \mathrm{abc}$ \\
\hline 7. & $\mathrm{~S}_{2} \mathrm{O}_{3}{ }^{2-}$ & $1: 1$ & $4.000 \mathrm{~cd}$ & $0.392 \mathrm{~b}$ & $1.630 \mathrm{bc}$ & $0.220 \mathrm{ab}$ & $2.463 \mathrm{abc}$ & $0.234 \mathrm{~cd}$ \\
\hline
\end{tabular}

Note: Data marked with the same letter is not significantly different at the significant level of $\mathrm{p}<0.05$

The N-content of spring wheat on sandy soil, as expected, was lower than $\mathrm{N}$-content of plant on chernozem soil, its value ranged between $2.139 \%$ and $4.218 \%$. All fertilised treatment significantly increased this value. Analysing the effect of different sulphur forms, higher $\mathrm{N}$-concentration was observed in the case of application of sulphate form with higher sulphur rates (treatment 3,4). Comparing the effect of treatment with different $\mathrm{N}: \mathrm{S}$ ratio, significantly higher $\mathrm{N}$-content was measured with increasing sulphur doses, but this increment was observed only by using the sulphate form.

The variations of sulphur content of spring wheat on sandy soil (0.344-0.475\%) showed the same tendencies as the changes on the chernozem soil.

The nitrogen-content of plants ranged between 1.701 and $2.399 \%$ in all treatments at the stage of BBCH 65-69 on chernozem soil. The fertilised treatments significantly increased the $\mathrm{N}$-content of spring wheat compared to the control. Analysing the effect of the applied sulphur forms and the treatments with different $\mathrm{N}: \mathrm{S}$ ratios, there were no further changes in the $\mathrm{N}$-content.

The total sulphur-content of spring wheat varied from 0.198 to $0.456 \%$ in all treatments. At this development stage, the treatments with sulphate form resulted significantly higher sulphur-content than treatments with thiosulphate form. The treatments with increasing sulphur doses had also significant effect on sulphur-content, higher sulphur-content was observed with higher sulphur rates.

On sandy soil, the total N-content ranged between 1.567 and $1.888 \%$. Significant enhancement in Ncontent was found in all fertilised treatments. The treatments with sulphate form resulted higher $\mathrm{N}$ content than the treatments with thiosulphate S-source. The applied N:S ratios did not change significantly these values, however the increasing sulphur doses of the used sulphur forms influenced the $\mathrm{N}$-content differently, which means the increasing doses of sulphate form decreased, while the increasing level of thiosulphate form slightly increased the $\mathrm{N}$-content.

The total sulphur content varied from 0.180 to $0.403 \%$. In general, the increasing sulphur doses enhanced this value. Examining the differences between the applied sulphur sources it can be established that the treatments with sulphate form resulted significantly higher sulphur-content.

The concentration of total $\mathrm{N}$ in wheat grain on chernozem soil varied from 1.732 to $2.020 \%$. Klikocka et al. (2017) estimated higher values (2.54-2.88\%) in their experiment with spring wheat. Similar values (2.33-2.88\%) were obtained by Reussi et al. (2011), who also conducted experiments with spring wheat to determine sulphur deficiency. In our experiment the highest value was found after the application of $120 \mathrm{~kg}$ 
$\mathrm{S} \mathrm{ha}^{-1}$ in sulphate form (treatment 4 ). The effect of increasing sulphur doses on $\mathrm{N}$-content prevailed only in the case of application of sulphate forms. In studies of Martin (1997) and Reussi et al. (2011), the increasing level of sulphur increased noticeably the $\mathrm{N}$ content in grains of wheat.

The total sulphur-content of spring wheat grain ranged between $0.153 \%$ and $0.180 \%$. In studies of Klikocka et al. (2017), lower sulphur content of spring wheat grain was measured $(0.124-0.140)$. In our experiment, the sulphur content of grain was all similar and not significantly different from the unfertilised control. However, several works carried on different crops, determined increase in grain $\mathrm{S}$ concentration by S fertilisation (Moss et al., 1981; Prystupa et al., 2006; Zhao et al., 2006). The lack of response at fertilised treatments, which by the way showed yield increase by $\mathrm{S}$ addition, could be explained by the late contribution of $\mathrm{S}$ through mineralization, thus enabling right $\mathrm{S}$ concentrations at crop.

The nitrogen-content of wheat grain on sandy soil ( 2.127 and $2.711 \%$ ) was higher than on chernozem soil, which can be describe as a result of higher biomass production on chernozem soil. The content of $\mathrm{N}$ in the spring wheat grain significantly increased by the rate of $60 \mathrm{~kg} \mathrm{~S}$ and $120 \mathrm{~kg} \mathrm{~S} \mathrm{ha}^{-1}$ in the case of application of sulphate form, however the highest content of $\mathrm{N}$ was found after the application of $60 \mathrm{~kg} \mathrm{~S} \mathrm{ha}^{-1}$ (treatment 3). In general the increasing sulphur doses resulted higher $\mathrm{N}$-content and the treatments with sulphate increased the N-content compared to the treatments with thiosulphate form.

On sandy soil, the sulphur content of grain ranged between $0.198 \%$ and $0.244 \%$ Significantly higher value was observed at the treatment $3\left(60 \mathrm{~kg} \mathrm{~S} \mathrm{ha}^{-1}\right)$. The effect of increasing sulphur doses prevailed only in the case of application of thiosulphate form, where the increasing sulphur levels enhanced the sulphur content of grain.

\section{The changes of $\mathrm{N}$ - and $\mathrm{S}$-uptake by spring wheat at different development stages}

The N- and S-uptake by spring wheat (Table 5) at the stage of BBCH 30-31 on chernozem soil did not change significantly with the application of different treatments.

Table 5. The changes of uptake of $\mathbf{N}$ and $\mathrm{S}$ by spring wheat at different development stages

\begin{tabular}{|c|c|c|c|c|c|c|c|c|}
\hline \multirow[t]{2}{*}{$\begin{array}{c}\text { Treatment } \\
\text { number }\end{array}$} & \multirow[t]{2}{*}{$\begin{array}{l}\text { Sulphur } \\
\text { forms }\end{array}$} & \multirow[t]{2}{*}{$\mathrm{N}: \mathrm{S}$ ratio } & \multicolumn{2}{|c|}{$\begin{array}{c}\text { BBCH 30-31 } \\
\text { whole plant } \\
\text { (mg/2plants) }\end{array}$} & \multicolumn{2}{|c|}{$\begin{array}{c}\text { BВCH } 69 \\
\text { leaves } \\
\text { (mg/2plants) }\end{array}$} & \multicolumn{2}{|c|}{$\begin{array}{c}\text { BBCH } 89 \\
\text { grain } \\
(\mathrm{mg} / \text { pot })\end{array}$} \\
\hline & & & N-uptake & S-uptake & N-uptake & S-uptake & N-uptake & S-uptake \\
\hline \multicolumn{9}{|c|}{ Chernozem soil } \\
\hline 1. & - & control & $10.23 \mathrm{a}$ & $1.33 \mathrm{a}$ & $10.21 \mathrm{a}$ & $2.22 \mathrm{abc}$ & $114.8 \mathrm{a}$ & $9.75 a$ \\
\hline 2. & $\mathrm{SO}_{4}^{2-}$ & $1: 0.2$ & $12.08 \mathrm{a}$ & $1.38 \mathrm{a}$ & $17.32 \mathrm{ab}$ & $2.37 \mathrm{abc}$ & $208.6 b$ & $18.97 \mathrm{~b}$ \\
\hline 3. & $\mathrm{SO}_{4}^{2-}$ & $1: 0.5$ & $10.84 \mathrm{a}$ & $1.23 \mathrm{a}$ & $18.86 \mathrm{ab}$ & $3.67 \mathrm{c}$ & $228.7 b$ & $19.91 b$ \\
\hline 4. & $\mathrm{SO}_{4}{ }^{2-}$ & $1: 1$ & $11.31 \mathrm{a}$ & $1.20 \mathrm{a}$ & $15.27 \mathrm{ab}$ & $3.16 b c$ & $212.1 b$ & $18.24 \mathrm{~b}$ \\
\hline 5. & $\mathrm{~S}_{2} \mathrm{O}_{3}{ }^{2-}$ & $1: 0.2$ & $12.17 \mathrm{a}$ & $0.94 \mathrm{a}$ & $16.10 \mathrm{ab}$ & $1.39 \mathrm{a}$ & $193.0 \mathrm{~b}$ & $16.82 \mathrm{~b}$ \\
\hline 6. & $\mathrm{~S}_{2} \mathrm{O}_{3}{ }^{2-}$ & $1: 0.5$ & $11.44 \mathrm{a}$ & $1.32 \mathrm{a}$ & $21.97 \mathrm{~b}$ & $2.03 \mathrm{ab}$ & $202.2 b$ & $18.52 b$ \\
\hline 7. & $\mathrm{~S}_{2} \mathrm{O}_{3}{ }^{2-}$ & $1: 1$ & $11.25 \mathrm{a}$ & $1.11 \mathrm{a}$ & $16.87 \mathrm{ab}$ & $2.07 \mathrm{abc}$ & $194.2 b$ & $17.94 b$ \\
\hline \multicolumn{9}{|c|}{ Sandy soil } \\
\hline 1. & - & control & $3.69 \mathrm{a}$ & $0.82 \mathrm{a}$ & $3.11 \mathrm{a}$ & $0.56 \mathrm{a}$ & $56.5 \mathrm{a}$ & $5.16 \mathrm{a}$ \\
\hline 2. & $\mathrm{SO}_{4}{ }^{2-}$ & $1: 0.2$ & $18.40 \mathrm{~cd}$ & $1.91 \mathrm{~cd}$ & $11.84 \mathrm{~b}$ & $1.55 \mathrm{ab}$ & $138.4 b$ & $12.37 \mathrm{~b}$ \\
\hline 3. & $\mathrm{SO}_{4}{ }^{2-}$ & $1: 0.5$ & $20.83 d$ & $2.25 \mathrm{~d}$ & $10.61 b$ & $2.24 b c$ & $168.8 \mathrm{~b}$ & $12.57 \mathrm{~b}$ \\
\hline 4. & $\mathrm{SO}_{4}{ }^{2-}$ & $1: 1$ & $17.01 \mathrm{bcd}$ & $1.82 \mathrm{bcd}$ & $10.27 \mathrm{~b}$ & $2.54 \mathrm{c}$ & $140.9 \mathrm{~b}$ & $12.33 b$ \\
\hline 5. & $\mathrm{~S}_{2} \mathrm{O}_{3}{ }^{2-}$ & $1: 0.2$ & $13.94 \mathrm{bcd}$ & $1.19 \mathrm{abc}$ & $12.37 \mathrm{~b}$ & $1.45 \mathrm{ab}$ & $137.1 \mathrm{~b}$ & $13.50 \mathrm{~b}$ \\
\hline 6. & $\mathrm{~S}_{2} \mathrm{O}_{3}{ }^{2-}$ & $1: 0.5$ & $11.37 \mathrm{abc}$ & $1.05 \mathrm{abc}$ & $11.28 \mathrm{~b}$ & $1.19 \mathrm{a}$ & $146.7 \mathrm{~b}$ & $14.20 \mathrm{~b}$ \\
\hline 7. & $\mathrm{~S}_{2} \mathrm{O}_{3}{ }^{2-}$ & $1: 1$ & $8.72 \mathrm{ab}$ & $0.85 \mathrm{ab}$ & $10.70 \mathrm{~b}$ & $1.40 \mathrm{~b}$ & $154.7 \mathrm{~b}$ & $14.69 \mathrm{~b}$ \\
\hline
\end{tabular}

Note: Data marked with the same letter is not significantly different at the significant level of $\mathrm{p}<0.05$

On sandy soil, greater variations were observed in the $\mathrm{N}$ - and S-uptake by spring wheat. Application of $\mathrm{N}$ and $\mathrm{S}$ fertilisers increased the $\mathrm{N}$ - and $\mathrm{S}$-uptake by the plant. In the case of both nutrient uptakes, the lowest value was found in the control treatment and the maximum uptake was calculated in treatment $3(120 \mathrm{~kg}$ $\mathrm{N}$ and $\left.60 \mathrm{~kg} \mathrm{~S} \mathrm{ha}^{-1}\right)$. In the treatments with sulphate form, higher $\mathrm{N}$-and $\mathrm{S}$-uptake were detected than in the treatments with thiosulphate. The increasing doses of sulphur had no significant effect on the nutrient uptake.
At the stage of BBCH 65-69 on chernozem soil, the $\mathrm{N}$ - uptake by wheat was tended to be higher in all fertilised treatments, however, the highest uptake of $\mathrm{N}$ by wheat was found after the application of $120 \mathrm{~kg} \mathrm{~N}$ and $60 \mathrm{~kg} \mathrm{~S} \mathrm{ha}^{-1}$ (treatment 6). Furthermore, no significant differences were determined on uptake by $\mathrm{N}$ as effect of $\mathrm{N}$ and $\mathrm{S}$ addition.

In the case of uptake of sulphur, the maximum value was determined as a result of $120 \mathrm{~kg} \mathrm{~N}$ and $60 \mathrm{~kg} \mathrm{~S} \mathrm{ha}^{-1}$ addition (treatment 3). The treatments with sulphate form resulted higher sulphur-uptake by spring 
wheat than treatments with thiosulphate form. In addition, there were no significant differences between the applied N:S ratio treatments.

On sandy soil, the nutrient uptake by plant was lower than on chernozem soil. All fertilised treatments increased the $\mathrm{N}$ - and S-uptake by spring wheat compared to the unfertilised pots, but in the case of $\mathrm{N}$ uptake there was no further effect between the applied treatments. At treatments 3,4 and 7, significant increase in S- uptake was determined as a result of $\mathrm{N}$ and $S$ addition. Analysing the effect of two sulphur sources, the treatments with sulphate form were more effective than the treatments with thiosulphate and the effect of increasing sulphur doses only prevailed in the case of application of sulphate form.

The uptake of $\mathrm{N}$ and $\mathrm{S}$ by the wheat grain on chernozem soil significantly increased together with the $\mathrm{S}$ and $\mathrm{N}$ application and were the highest following the application of $120 \mathrm{~kg} \mathrm{~N}$ and $60 \mathrm{~kg} \mathrm{~S}^{-1}$ (treatment 3). Howarth et al. (2008) observed this effect, too, namely that $S$ fertilisation increased uptake of $S$ by grain. The various sources of sulphur did not show any significant improvement in sulphur and nitrogen uptake by wheat grain, however a little bit higher uptake of nutrients was recorded in the case of application of sulphate form. Sangwan et al. (2018) investigated the effect of different sulphur forms (elemental sulphur, gypsum, potassium sulphate and pyrite) on the nutrient uptake of wheat in a pot experiment and they came to similar conclusion, too. In their experiment, the treatments with potassium sulphate resulted the highest uptake of sulphur and nitrogen. The uptake of sulphur and nitrogen was not significantly influenced by the increasing level of sulphur.

The interaction between the increasing sulphur level and the applied S- sources resulted significant increase in sulphur and nitrogen uptake by spring wheat grain on sandy soil as well. However, further variances between the fertilised treatments were not observed, but there were visible some tendencies. In the case of $\mathrm{N}$ uptake, the highest value was observed in the treatment 3 (120 kg N and $60 \mathrm{~kg} \mathrm{~S} \mathrm{ha}^{-1}$ ), and it can also be observed that the treatments with sulphate form resulted a little bit higher nitrogen-uptake. In contrast, the sulphur uptake was tended to be higher in the case of application of thiosulphate form and with increasing level of thiosulphate higher sulphur uptake was observed.

\section{CONCLUSIONS}

In the greenhouse pot experiment the effects of fertilisation with two sulphur sources (sulphate and thiosulphate) with different $\mathrm{N}: \mathrm{S}$ ratio background were investigated on yield and nutrient content and uptake by spring wheat on chernozem and sandy soil. It is clearly prevailed that different sources and rates of $S$ application all affect seed yield, nutrient content and uptake by spring wheat.

On both chernozem and sandy soil, the maximum yield was observed in the case of application of $120 \mathrm{~kg}$ $\mathrm{N}$ and $60 \mathrm{~kg} \mathrm{~S} \mathrm{ha}^{-1}$ with $\mathrm{N}: \mathrm{S}=1: 0.5$ background. On chernozem soil, this effect was achieved with sulphate$\mathrm{S}$ form and on sandy soil with thiosulphate form.

In general, it can be concluded that on chernozem soil the increasing doses of sulphur $(24,60,120 \mathrm{~kg} \mathrm{~S}$ $\left.\mathrm{ha}^{-1}\right)$ with the same $\mathrm{N}$ dose (120 $\left.\mathrm{kg} \mathrm{N} \mathrm{ha}^{-1}\right)$ increased the $\mathrm{N}$-content of spring wheat at all development stages and in the wheat grain. The treatment with different sulphur sources did not cause further changes in the $\mathrm{N}$ content.

On sandy soil, in the most cases the $\mathrm{N}$-content did not change significantly as a result of increasing sulphur doses. The treatments with sulphate form basically resulted higher nitrogen-content than treatments with thiosulphate form.

The treatments with increasing sulphur doses resulted higher S-content on both of chernozem and sandy soil in the case of all development stage. Comparing the effect of the applied sulphur sources on the S-content, it can be stated that at the stage of BBCH 30-31 and 65-69 the treatments with sulphate form resulted higher sulphur-content, because at these development stages the thiosulphate may not have been available yet to the plant (thiosulphate should be oxidised first to be taken up by plant). However, at the stage of BBCH 89 there were no significant differences in S-content of grain as a result of different sulphursources.

At the stage of $\mathrm{BBCH} 30-31$, the applied treatments influenced the $\mathrm{N}$-and S-uptake by wheat only on sandy soil. The treatments with sulphate form resulted higher nutrient uptake, but the increasing sulphur doses had no effect on these values. At the stage of BBCH 65-69 on both of chernozem and sandy soil, the fertilised treatments did not influence significantly the $\mathrm{N}$-uptake by wheat. The S-uptake was higher as a result of treatments with sulphate form, but the treatments with increasing sulphur doses did not change the uptake by sulphur.

On both chernozem and sandy soil, there was no significant differences in the nutrient uptake by wheat grain as a result of increasing doses of sulphur and the different sulphur sources.

\section{REFERENCES}

Aula, L.-Dhillon, J.S.-Omara, P.-Wehmeyer, G.B.-Freeman, K.W.-Raun, W.R. (2019): World Sulphur Use Efficiency for Cereal Crops, Agronomy Journal Vol. 111 (5): 2485-2492. doi.org/10.2134/agronj2019.02.0095
Balanagaudar, S.R.-Satyanlyana, T. (1990): Depth distribution of different forms of sulphur in Vertisol and Alfisols. J. Indian Soc. Soil Sci. 38: 634-640.

Blake-Kalff, M.M.A.-Hawkesford, M.J.-Zhao, F.J.-McGrath, S.P. (2000): Diagnosing sulfur deficiency in field-grown oilseed rape 
(Brassica napus L.) and wheat (Triticum aestivum L.). Plant and Soil, 225: 95-107. doi.org/10.1023/A:1026503812267

Brook, R.H. (1979): Abstract on Tropical Agric. 5: 9.

Dick, W.A.-Kost, D.--Chen, L. (2008): Availability of Sulfur to Crops from Soil and Other Sources, in: Sulfur: A Missing Link between Soils, Crops, and Nutrition, Volume 50, Chapter 5. 5982. American Society of Agronomy, Inc. Crop Science Society of America, Inc. Soil Science Society of America, Inc. doi: 10.2134/agronmonogr50.c5

Fotyma, E. (1990): Identify needs fertiliser plants in relation to the N on the example of spring barley. Fragm. Agron., 4(28), 4. [In Polish]

Germida, J.J.-Janzen, H.H. (1993): Factors affecting the oxidation of elemental sulfur in soils. Fertiliser Research 35, 443-455. doi.org/10.1007/BF00750224

Howarth, J.R.-Parmas, S.-Jones, J.-Shepherd, C.E.-Corol, D.I.Galster, A.M.-Hawkins, N.D.-Miller, S.J.-Baker, J.M.-Verrier P.J.-Ward, J.L.-Beale, M.H.-Barraclough, P.B.-Hawkesford, M.J. (2008): Co-ordinated expression of amino acid metabolism in response to $\mathrm{N}$ and $\mathrm{S}$ deficiency during wheat grain filling. J. Exp. Bot., 59 (13), 3675. doi: 10.1093/jxb/ern218

Jamal, A.-Moon, Y.S.-Abdid, M.Z. (2010): Sulphur - a general overview and interaction with nitrogen. Australian Journal of Crop Science, 4 (7): 523-529.

Janzen, H.H.-Bettany, J.R. (1986): Release of available S from fertilisers. Canadian Journal of Soil Science 66, 91-103. doi.org/10.4141/cjss86-010

Järvan, M.-Edesi, L.-Adamson, A.-Lukme, L.-Akk, A. (2008): The effect of sulphur fertilisation on yield, quality of protein and baking properties of winter wheat. Agronomy Research, 6 (2): 459-469.

Klikocka, H.-Cybulska, M.-Nowak A. (2017): Efficiency of fertilisation and utilisation of nitrogen and Sulphur by spring wheat, Pol. J. Environ. Stud. Vol. 26 (5): 1-8. doi.org/10.15244/pjoes/69942

Klikocka, H.-Marks, M.-Barczak, B.-Szostak, B.-Podleśna, A.Podleśny, J. (2018): Response of spring wheat to NPK and S fertilisation. The content and uptake of macronutrients and the value of ionic ratios, Open Chem., 2018; 16: 1059-1065. doi.org/10.1515/chem-2018-0116

Martin, R.J. (1997): Uptake and distribution of N and S in two Otane wheat crops. Proceedings Agron. Society N.Z., 27, 19.

McGrath, S.P.-Zhao, F.J.-Withers, P.J.A. (1996): Development of sulphur deficiency in crops and its treatment. Proceedings of the Fertiliser Society (Peterborough) 379, 1-48.

Messick, D.L.-Fan, M.X.-de Brey, C. (2005): Global sulphur requirement and sulphur fertilisers. Landbauforschung Völkenrode, 283 (spec. iss.): 97-104.
Moss, H.J.-Wrigley, C.W.-Macritchie, F.-Randall, P.J. (1981): Sulfur and nitrogen fertiliser effects on wheat. II. Influence on grain quality. Australian Journal of Agricultural Research 32: 213-226. doi.org/10.1071/AR9810213

Olfs, H.W.-Fuchs, M.-Ortseifen, U.-Schintling-Horny, L.-von Chappuis, A.-Zerulla, W.-Erdle, K. (2012): Schwefel Düngung effizient gestalten. Fachzentrum Land- und Ernährungswirtschaft. DLG-Merkblatt 373: 4-26. (in German).

Podleśna, A. (2013): Studies on the role of sulfur at forming of mineral management and height and quality of chosen crops yield. Habilitation thesis. Monografie i rozprawy naukowe 37. IUNG Puławy, 2013 [In Polish]

Prystupa, P.-Boem, F.H.-Salvagiotti, F.-Ferraris, G.-Couretot, L. (2006): Measuring corn response to fertilisation in the northern pampas. Better Crops 90: 25-27.

Reussi, N.-Echeverría, H.-Rozas, H.S. (2008): Usefulness of Foliar Nitrogen-Sulfur Ratio in Spring Red Wheat, Journal of Plant Nutrition, 31: 1612-1623. doi.org/10.1080/01904160802244829

Parsons, J.W.-Tinsley, J. (1975): Nitrogenous substances. In Soil Components Vol. I (J.E. Gieseking, Ed.), Springer-Verlag, Berlin and New York. 263-304.

Reussi, N.-Echeverria, H.-Rozas H.S. (2011): Diagnosing sulfur deficiency in spring red wheat: plant analysis. J. Plant Nutr., 34 (4), 573. doi: 10.1080/01904167.2011.538118

Saad, O.A.L.O.-Lehmann, S.-Conrad, R. (1996): Influence of thiosulfate on nitrification, denitrification, and production of nitric oxide and nitrous oxide in soil. Biology and Fertility of Soils 21, 152-159. doi.org/10.1007/BF00335927

Sangwan, A.-Duhan, B.S.-Sangwan, P.S. (2018): Effect of different sources of sulphur on yield and nutrient uptake by wheat. Journal of Prarmacognosy and Phytochemistry, 7(6) 2686-2691.

Schnug, E.-Haneklaus, S. (1998): Diagnosis of sulphur nutrition, in Schnug, E. (ed): Sulphur in agroecosystems. Kluwer Acad., Publ., Dordrecht, Boston, London. 1-38. doi: 10.1007/978-94011-5100-9_1

Sullivan, D.M.-Havlin, J.L. (1992): Thiosulfate inhibition of urea hydrolysis in soils: tetrathionate as a urease inhibitor. Soil Science Society of America Journal 56, 957-960. doi.org/10.2136/sssaj1992.03615995005600030045x

Tiwari, K.N.-Nigam, V.-Pathak, A.N. (1985): Evaluation of some soil test methods for diagnosing $\mathrm{S}$ deficiency in alluvial soils of U.P. Bull CSAUA Kanpur 46

Zhao, F.J.-Fortune, S.-Barbosa, V.L.-McGrath, S.P.-Stobart R., Bilsborrow, P.E.-Booth, E.J.-Brown, A.-Robson, P. (2006): Effects of sulphur on yield and malting quality of barley. Journal of Cereal Science, 43 (3): 369-377. doi.org/10.1016/j.jcs.2005.12.003 
